\title{
RAZGOVOR SA ŠKOLSKOM PSIHOLOGINJOM JASMINKOM ZAGORAC
}

\author{
DOI $10.17234 / 9789531757782.14$
}

Jasminka Zagorac većinu je svojega radnog vijeka provela kao stručna suradnica psihologinja te nastavnik u Školi za cestovni promet u Zagrebu. Prije škole radila je kao odgajatelj u učeničkom domu u sklopu Školskog centra za cestovni saobraćaj, a od 1986. zaposlena je u punom radnom vremenu u stručnoj službi spomenute škole kao njezin prvi psiholog stručni suradnik. $S$ toga radnog mjesta otišla je u mirovinu 2015. godine. Jasminka je prva stručna suradnica psihologinja promovirana u zvanje savjetnika. Nesebično prenoseći svoje znanje i iskustvo te podržavajući kolege na njihovom profesionalnom putu, Jasminka je bila savjetnica u pravom smislu te riječi. Autorica je i koautorica članaka i priručnika iz područja prevencije i psihologije obrazovanja. Pokretanjem i osmišljavanjem brojnih aktivnosti te razvijanjem i obogaćivanjem različitih područja rada školskog psihologa, znatno je pridonijela važnosti i prepoznatljivosti radnog mjesta psihologa u životu škole te u obrazovnom sustavu. Dobitnica je Društvenog priznanja Hrvatskog psihološkog društva za osobit doprinos razvitku primijenjene psihologije u Hrvatskoj "Marulić: Fiat Psyhologia" za 2014. godinu.

Kojim ste se poslovima, na početku karijere ali i kasnije, najviše bavili kao psiholog uskoli?

Kao stručna suradnica psihologinja najviše sam se bavila područjem profesionalnog preusmjeravanja, preventivnim programima i savjetodavnim radom $s$ učenicima i roditeljima te sam radila $s$ nastavnicima, osobito $s$ nastavnicima pripravnicima. Prvih godina obavljala sam i poslove vezane za upis u prvi razred te formirala razredne odjele.

Područje profesionalnog preusmjeravanja obuhvaćalo je učenike koji su tijekom školovanja morali biti premješteni u neki drugi program u istoj ili drugoj školi. To nije uvijek bilo jednostavno zbog lošijega školskog uspjeha učenika, zdravstvenih poteškoća i sl. Naime, kod upisa u prvi razred učenici nisu prolazili liječnički pregled pa je postojanje kontraindikacija za prometno zanimanje, pogotovo za zanimanje vozač motornog vozila, otkrivano tijekom školovanja. Zbog toga sam radila na uvođenju liječničkih pregleda pri upisu u prvi razred kako bi se na vrijeme utvrdile eventualne kontraindikacije za navedena zanimanja. Danas je nepostojanje kontraindikacija uvjet za upis u zanimanje vozač. 
U savjetodavnom radu prevladavali su razgovori s učenicima koji su imali teškoća u učenju, problem izostajanja iz škole, teškoće prilagodbe na novu školsku sredinu, emocionalne teškoće te obiteljske probleme. Česta tema u radu $s$ učenicima bilo je nenasilno rješavanje sukoba, kao i radionice i predavanja namijenjena usvajanju tehnika učenja.

Iskustvo rada s grupama učenika u učeničkom domu potaklo me da i u školi uvedem grupni rad $s$ učenicima u svim segmentima savjetodavnog rada. Ovakav oblik rada omogućuje da se na pozitivan način iskoristi utjecaj i podrška vršnjaka u rješavanja problema, čime se postiže vidljivi napredak kod pojedinaca. Za postizanje jasne strukture savjetodavnog razgovora te kvalitetnih ishoda vrlo mi se korisnom pokazala realitetna terapija (teorija izbora), za koju sam završila edukaciju.

Preventivne aktivnosti i programi bili su usmjereni na razvijanje i poticanje zdravih životnih navika, važnih za sigurnost u prometu i podizanje kvalitete života općenito. U sklopu tih aktivnosti osmislila sam i izdala brošuru za učenike Cuvajmo zdravlje, alkohol stop.

Cijeli svoj radni vijek predavala sam i predmete iz područja prometne psihologije u redovnoj školi i obrazovanju odraslih te sam sudjelovala u kreiranju programa za te predmete a izdala sam u koautorstvu i udžbenik Prometna psihologija i kultura.

Osim direktnog rada sa sudionicima u obrazovnom procesu, s kolegicama iz drugih škola provela sam brojna istraživanja vezana uz preventivne aktivnosti koje smo provodili u školama, školski uspjeh, izostanke, slobodno vrijeme, a rezultate smo prezentirali na konferencijama psihologa i na drugim stručnim skupovima.

U cijelom svom radnom vijeku sudjelovala sam kao predavač i voditelj radionica na županijskim, državnim i međunarodnim stručnim skupovima psihologa, pedagoga, ravnatelja, nastavnika i nastavnika pripravnika. To su bila lijepa druženja i iskustva.

Uključivala sam se i u međunarodne projekte poput onog na temu savjetodavnog rada te socijalne isključenosti u srednjim strukovnim školama. Osobito vrijedno i drago iskustvo bilo mi je sudjelovanje u projektu Građanskog odgoja, za koji sam bila državni koordinator, jer je taj projekt usmjeren na razvijanje različitih socijalnih vještina učenika te na senzibilizaciju učenika za rješavanje problema u lokalnoj zajednici i promicanje ljudskih prava. Nezaboravan doživljaj bio je predstaviti u Američkom kongresu važnost Projekta gradanin i značaj suradnje učenika različitih kultura.

Kada ste počeli raditi u školi, bilo je tek nekoliko psihologa stručnih suradnika u srednjim školama u Zagrebu. Danas skoro svaka srednja škola ima psihologa. Kada je došlo do promjene, tj. do porasta broja zaposlenih psihologa po školama?

Prema tadašnjem pedagoškom standardu, predviđeno je da jedan psiholog radi $s$ vrlo velikim brojem učenika. Osim toga, zakon je propisao da škola može 
imati psihologa ili pedagoga, pa su mnoge škole imale samo pedagoga, no ne i stručnog suradnika psihologa.

Psiholozi su se počeli više zapošljavati u školama tijekom i nakon Domovinskog rata. U Zagreb je došlo puno ljudi prognanih iz svojih prebivališta i njihova su djeca nastavila školovanje ovdje. Višestruke traume, gubitak članova obitelji, imovine, škole i prijatelja, stres uzrokovan ratom samo su neki od problema s kojima se društvo tada prvi put suočilo. Postala je sve veća potreba za psiholozima u svim segmentima društva, pa tako i u odgojno-obrazovnim djelatnostima.

Koje su još promjene u radu školskih psihologa, po Vašem mišljenju, nastupile u ratno i poratno vrijeme?

$S$ početkom rata, po odluci resornog ministarstva, a u suradnji sa savjetnicima iz Zavoda za školstvo, osnovana su županijska stručna vijeća, na kojima su se izmjenjivala iskustva i obrađivale teme vezane uz rad stručnog suradnika. $U$ početku su ova vijeća bila zajednička za pedagoge i psihologe, a s vremenom je ipak došlo do njihovog razdvajanja. Kako se povećavao broj psihologa zaposlenih na mjestu stručnog suradnika, stručna vijeća podijelila su se na strukovne škole i gimnazije jer je uočeno kako svakodnevni poslovi i zahtjevi koje pred psihologa postavljaju ove dvije vrste škola nisu jednaki. Danas su ta vijeća puno učinkovitija nego na svojim počecima.

Obveza polaganja stručnih ispita uvedena je nakon rata (1996. godine); upravo su u mojoj školi taj ispit polagali stručni suradnici iz svih srednjih škola u Hrvatskoj. Bila sam član povjerenstva na tim ispitima, ali i mentor psiholozima stručnim suradnicima do stručnog ispita. Tada sam počela intenzivnije surađivati s Odsjekom za psihologiju postavši mentor studentima u području metodike nastave psihologije, a bila sam i dugogodišnji vanjski suradnik nadležnih agencija za obrazovanje.

Iako su se sve više otvarala radna mjesta za psihologe u školama, nisu svi imali sreću da se mogu baviti isključivo poslovima stručnog suradnika psihologa jer stručne službe nisu bile ekipirane pa su mladim psiholozima, često i na početku njihovog rada, dodijeljeni poslovi administrativnog karaktera poput pisanja dopisa, zapisnika, organizacije nastave i rasporeda i sl. Vjerujem da je danas drugačije.

\section{S kojim ste se poteškoćama susretali na početku svog rada, a koje su otežavale tada posao školskog psihologa?}

To su prvenstveno nedostatna promocija struke i neprepoznavanje poslova i važnosti psihologa u školama, zatim nedovoljno organizirana razmjena iskustava, što smo rješavali međusobnim druženjem i neformalnom razmjenom iskustava.

U početku moga rada u školi bilo je malo psihologa u srednjim školama. Nismo imali službene mentore pa smo se snalazili međusobno izmjenjujući iskustva. 
Programe smo stvarali i strukturirali poslove školskog psihologa nalazeći se u slobodno vrijeme. Budući da u školama nije bilo računala sa statističkim programima, u provođenju istraživanja snalazili smo se na razne načine kako bismo obradili podatke. Osim toga, problem je bila i dostupnost mjernih instrumenata i upitnika; mnoge smo upitnike sami izrađivali za potrebe tih istraživanja. Zahvaljujući svemu tome, to su ipak bila lijepa i kreativna vremena. Tada nije bila dostupna stručna literatura iz psihologije obrazovanja na hrvatskom jeziku, pa smo sami prevodili literaturu koja nam se činila korisnom za naš posao. Nedostajalo je i sustavnih edukacija namijenjenih psiholozima koji rade u školama. Sve to je kasnije postalo dostupnije, kako literatura tako i brojne edukacije, a mladi, tek zaposleni psiholozi, imaju mentore koji ih vode kroz pripravnički staž, do stručnog ispita.

Koje su osobe koje ste susreli na svom radnom putu posebno utjecale na Vaš profesionalni razvoj?

Kroz svoj radni vijek radila sam i surađivala $s$ mnogim ljudima od kojih sam puno naučila i koji su mi pomogli u mom profesionalnom rastu i razvoju. Posebice bih istaknula suradnju s mojim dragim kolegicama s Odsjeka za psihologiju Filozofskog fakulteta u Zagrebu, Vlastom Vizek Vidović (koja, nažalost, više nije s nama) i Vesnom Vlahović -Štetić. S njima sam radila od početka uvođenja stručnih ispita i kao vanjski suradnik fakulteta na kolegiju Metodika nastave psihologije. Meni važna osoba bila je i naša savjetnica, psihologinja Teodora Dubrović, koja također, nažalost, više nije $s$ nama. Radile smo zajedno na različitim projektima, na provođenju stručnih ispita, planiranju i provođenju različitih edukacija. Kroz intenzivnu stručnu suradnju razvile smo i bliski prijateljski odnos. Nažalost, neke zajedničke započete projekte nismo uspjele dovršiti.

\section{Koja faza, godine posla su Vam bili najveći izazov?}

Svaka faza, svaki radni zadatak bili su mi izazov. No, možda jedan od najvećih izazova bili su mi sami počeci. Kada sam se zaposlila u školi, stalno sam morala u školi dokazivati što radi psiholog, koja je svrha toga novog radnog mjesta. No, kolege su i sami prepoznali važnost toga. Sjećam se kada su govorili da „u sobu psihologa učenici i roditelji ulaze u suzama, a iz nje izlaze sa smiješkom“. Ravnatelj je tada komentirao: „Dobro da nije obrnuto!“

\section{Kako danas gledate na godine provedene na poslovima školskog psihologa?}

Cijeli svoj radni vijek kao školski psiholog radila sam s adolescentima. Kroz moju sobu prošle su mnoge priče o različitim životnim situacijama, svakodnevnim brigama i strahovima, traženju sebe i o svemu što muči mlade ljude, ali i one o 
lijepim stvarima koje su se događale mojim učenicima. Bila sam tamo za njih. I danas imam osjećaj zadovoljstva kad pomislim da sam i ja svojim radom pomogla tim mladim ljudima na njihovu putu odrastanja.

Voljela sam svoj posao i da moram ponovno birati zanimanje, psihologija bi opet bila na vrhu ljestvice izbora.

Razgovor vodila Irena Ničota 